\title{
An Arrogant Conqueror in Nature ---- A new view on Patrick White's Voss*
}

\author{
Xiang Lan \\ School of Foreign Languages, University of Xihua, Chengdu, Sichuan Province, P.R. China \\ Xiangl.1203@aliyun.com
}

\begin{abstract}
If we consider Patrick White's novel in green and read his works for their ecological content we can see nature writ large in White's novel Voss: In the novel, Voss, an ego-centric German fails in his attempt to conquer nature. This article seeks to reveal how the author's eco-sense is conveyed in his most notable works.
\end{abstract}

Index Terms - Eco-critics, Patrick White, Voss

\section{Introduction}

Thoreau writes in Walden: 'We must learn to reawaken and keep ourselves awake...To affect the quality of the day, which is the highest of arts. Every man is asked to make his life, even its details, worthy of the contemplation of his most elevated and critical hour'. 'Thus observation of nature will help us enlarge the minutes of our lives and become more deeply conscious of our human limitations as Thoreau does. ${ }^{2}$

Eco-criticism is the interdisciplinary study of literature and the environment in which all the sciences are combined to analyze environmental problems. In response to the environmental crisis which humanity faces we must re-image our relationship with nature as on our very existence depends.

Nature's attraction is particularly strong in Australia, the island continent, seemingly beyond time and the exigencies of the industrialized world. We might ask, exactly what it meant for an European culture to plant with little fore thought an offshoot of its civilization upon Aborigines in their timeless land. This question has been asked by Patrick White.

Patrick White (1912-1990) a 20th century novelist inherited the mores and the prejudices of 19th century England, Europe and Australia. He was born in London, grew up in Sydney and NSW where his father owned a sheep farm, but educated in England. After serving in the RAF during WWII, he returned to Australia.

Patrick White was brought up in a wealthy pastoral family, similar to that for the poetess, Judith Wright who was deeply engaged with various environmental concerns, ranging from a fascination with birds to a dedication to protect the Great Barrier Reef. Quite differently, combined with the disaster he had witnessed of WWII, White became sensitive to the short comings of the society Europe had transplanted in Australia and the themes of his writing explore some of its deficiencies which were clear to him.

\footnotetext{
*This work is partially supported by SC13B Grant 076 to Xiang Lan

${ }^{1}$ Henry Thoreau, Walden

http://www.gutenberg.org/catalog/world/readfile?fk_files=2121329

${ }^{2}$ Scott Slovic, Seeking awareness in American Nature Writing University of Utah Press 1992. 8
}

Patrick White gained his appreciation and awareness of nature during his education in Europe, as well as from the landscapes of Australia. As he described in his autobiography, during the war he had thought with longing of the Australian landscape. Benefiting from his interest in literature and writing, he successfully expressed his Eco-sense of nature in many of his works. Voss is one of them.

This paper explores Patrick White's eco-sense in the novel Voss (1957) which reveals the truth of the tragic results of man's attempted conquest of Nature in Australia.

Enlightenment is gained from the failure of the arrogant hero Voss. His expedition team ended in tragedy caused by his blind attempt to conquer nature and his lack of the knowledge on the Australian desert environment and the Aborigines, all vital for his success. White's idea is expressed at the end of the novel with these words "He was never God, though he liked to think that he was. Sometimes, when he forgot, he was a man." ${ }^{3}$. Nature can never be conquered by any human beings no matter how great their vanity is.

\section{"We had seen God in his splendors, \\ Heard the next that Nature renders, \\ We had reached the naked soul of man." 4}

Ernest Shackleton

Man forgives, nature censures and defeats man's weakness. If Voss could have understood a vision such as Shackleton's, his exploration might have been a successful one. It is the purpose of this paper to show how Patrick White develops the bizarre center character of Voss and indirectly expresses the eco-sense in his understanding of man qua child of nature.

\section{A Lesson from Life}

White bases the story, in part only, on the 1848 expedition led by the German, explorer, Leichardt who vanished without trace while attempting to traverse northern Australia from Moreton Bay (Brisbane) to Perth in 1848. It also has overtones of the disharmony, lack of leadership and disaster of the ill fated Burke and Wills expedition of 1861.

The novel Voss is not historically accurate as the truth is unknown. However White borrows from the known history of the Burke and Wills expedition and Voss' character is to some extent an exaggerated copy of Burke's. Burke is hostile to the otherwise friendly Aborigines. He overruled others'

\footnotetext{
${ }^{3}$ Patrick White, Voss New York 1957. hereafter page references are cited in the text in parentheses

${ }^{4}$ Ernest Shackleton, Endurance: Shackleton's Incredible Voyage
} 
suggestions and decided to attempt to reach the furthest outpost of pastoral settlement while they were in poor condition, resulting in only one survivor. The one survivor of the final party who had reached the Gulf was John King, who found a group of the Yandruwandha tribe willing to give him food and shelter.

Voss schemed to be the leader of an exploration expedition to northern Australia with the objective to cross the continent. His arrogance and control mania lead to his ignorance of the natural Australian environment and ensured the expedition's failure with death of himself and all but one of the members. Voss' expedition vanished without a trace, mirroring Leichardt's attempt at the crossing which had reinforced the belief of the early settlers that Australia's interior was a foreboding, dangerous place. ${ }^{5}$

\section{An Arrogant Leader}

The hero of White's novel, Voss is an enigmatic figure, arrogant, completely isolated from man qua man; and the purpose of his expedition is not for the understanding of nature but for his own ambition for conquest. As John A. Weigel comments that the author compares Hitler with the fanatic leader Voss, ${ }^{6}$ and he has an excuse, that the makeup of his party is foisted upon him by his colonial "sponsors," it is clear that he would have preferred to travel alone. He believes that he has become a Romantic "project" of the colonials, and he remains spiritually aloof or probably psychotic throughout his life. White has megalomaniac Voss regard himself as a god from Europe destined to conquer the mysterious center of the continent, where as he is really a victim of his own vanity.

In order to emphasis the hero's arrogance, White writes this expedition novel in an unusual way, which, although dedicated to the achievement of desert traversal, is really an exploration of the psychology of explorers rather than developing knowledge of the characteristics of the desert country. As White writes himself:

Voss is 'the fiend of motion', a man of compulsive activity and movement. For Voss the ideal image is always somewhere else, somewhere mysterious, remote, out of reach. For him the Goddess is a seductive presence at the borders of consciousness, a figure that inspires activity by beckoning him into continental interiors and secret places. His bondage is not to the maternal earth beneath his feet, but to the dark inspiration who leads him to his ruin. ${ }^{7}$

\section{Ignorant of Nature's Laws}

After visiting the patron, Voss begins to recruit his expedition members with no consideration of exploring nature at all. A boy, Harry Roberts, idolizing Voss as benefactor and hero. The sickly Palfreyman, an ornithologist commissioned by an Englishman to make a collection of Australian flora and fauna. The third member is the itinerant Frank Le Mesurier

\footnotetext{
${ }^{5}$ Cranston, C.A.,Zeller, Robert, Literature in the Arid Zone: Australian Contexts and Their Writers Jan.01, 2007, Rodopic, Amsterdam, ISBN:9789401204514. 82

${ }^{6}$ John A. Weigel Patrick White Miami University, by G. K. Hall \& company, Twayne Publishers. 198348

${ }^{7}$ Patrick White, Ed.David Marr. Letters Sydney: Random House, 1994.188
}

who believes the expedition may provide him self-knowledge. The last member, the self confessed drunkard, Turner has forced himself on Voss, with assurances of being reliable.

When Voss invites Mesurier to join the expedition he muses, 'in this disturbing country,...it is possible more easily to discard the inessential and to attempt the infinite. You will be burnt up most likely, you will have the flesh torn from your bones, you will be tortured probably in many horrible and primitive ways, but you will realize that genius of which you ... suspect you are possessed, ... you will not tell me you are afraid.' (35-36)

This is a good example of how the German leader, surely in White's imagination a spiritual premonition in Voss of the fascist Hitler, as to how he seduces another puerile male into joining him in an orgy of disintegration. Voss teaches him to despise the realm of the limitations and the mortality of human beings, and 'to attempt the infinite', which, Voss describes, as 'a savagely masochistic plunge into the primeval void'. ${ }^{8}$

Another partner Judd, a recently freed convict, has the experience of the desert. "a man of physical strength and moral integrity"(18). During discussions Judd expresses sensible opinions which Voss chooses to ignore. Needless to say, Voss' sole purpose of the expedition is to conquer, so he refuses accept the possibility of his failure trapped as he is, in the madness of self-centered personality.

Turner, a drunkard member, announces that Voss' followers have "contracted with a practicing' madman... for a journey to hell a 'back" (43) In the conference between Voss and the other three members, he tries to define his own commitment, admitting the only reason he wants to cross the continent is because he desires to know it with his heart, which has nothing to do with scientific investigation, or with the nature itself: "why I am pursued by this necessity," he says, "it is no more possible for me to tell than it is for you, who have made my acquaintance only before yesterday” (29).

Le Mesurier appears to understand, when Voss predicts that he will immolate himself, Le Mesurier shouts: "you are mad." Whereupon Voss answers "If you like" (31)

With a number of settlers and two Aborigines, the team heads inland from the east coast facing difficulties from the very beginning. First, across drought-plagued desert then through waterlogged plains until they are forced to retreat to a cave where they lie for weeks waiting for a break in the weather. The expedition, risking life and limb, travels through both dry and wet country, meeting adversity at every step.

In Voss, the hero Voss fails abysmally to come to terms with the destructive force of the mother-world. He is used up by the timeless landscape. ${ }^{9}$ The landscape, which had earlier seemed to surround and embrace Voss, is further animated. The earth has become a living presence, a realm of famine figures and forms, a landscape comes out with the image of the Great Mother: "all the immediate world was soon swimming in the same liquid green. She was clothed in it. Green shadows almost disguised her face..." (198) White

\footnotetext{
${ }^{8}$ David Taccey: Patrick White, Fiction and unconscious, Melbourne Oxford University Press Auckland Oxford New York 1988,71,

${ }^{9}$ Ibid.: 90
} 
discovers the reasons why Voss' selfish love leads to his failure and his death.

During the expedition Voss pays no attention to the laws of nature but only to its conquest at the sacrifice of food, of the loyalty of his dog, of his companions' lives and finally of his own life. Voss and his inner circle are intent on ' $m a d$ things' and strive to 'blow the up world'. " 'people of that kind will destroy what you and I know' says the voice of conscience," and "It is a form of madness with them", (255)

Loyalty patterns begin to shift and the expedition then follows a downward course to its destiny of failure. He cannot find, obtain or invent any solution. The group splits on a serious issue, namely, either to believe in his visionary ability or to trust Judd's knowledge. To all it is obvious that the experienced Judd knows the wilderness much better than Voss, and those not blinded by faith in Voss prefer Judd as leader. Judd has realistic doubts about what Voss intends to do yet inevitably he helps reinforce Voss' self-image as a god and so emerges as Voss' betrayer, his Judas. Incredibly Voss finally imagines himself as the Saviour. ${ }^{10}$

\section{Completely Egocentric}

His personality degenerates further, envy driving him to reject all natural instincts of love. Judd is the focus of his envy and the dog that he loves is his victim. Envy destroys his natural instinct of love convinced as he is a god able to conquer all, including his companion Judd and to this end at the sacrifice of his lovely dog.

In the description of the death of the dog White shows great sympathy to both the dog and his master. Judd has detected Voss' affection for the dog Gyp, and says to Voss the dog is in good condition with nothing to do. When all reject killing the dog, Judd remains silent. Voss grins painfully.

'I would like very much to be in a position to enjoy the luxury of sentiment," Voss had spoken a few words to her, and was looking into the eyes of love, he pulled the trigger. He was cold with sweat. He could have shot off his own jaw. Yet, he had done right, he convinced himself through his pain, and would do better to subject himself to... discipline. (283-4)

If Voss has not killed the dog, perhaps the dog may have saved his life at the critical moment later in the expedition. Sadly because of the conflict between expedition members the loyal dog dies at her master's hand. Without the conflict, with Judd's experience, perhaps with Voss' strong will, the help of the dog and rest of the party, the expedition might have succeeded. Sadly enough the truth is that Voss is so meanspirited, so paranoid, as to be incapable of thinking of anyone else but himself and his expedition. He, with his self obsession, is the victim of his delusions which produce their ill-fated chain of errors that bedevil the expedition from its very beginning.

There are other passages in the novel which also express this idea, such as "the party entered the approaches to hell, with no sound but that of horses passing through a desert, and salt bush grating in the wind" (331) They may have some

\footnotetext{
${ }^{10}$ John A. Weigel Patrick White Miami University, Twayne Publishers. 1983.95
}

sense of psychological evocation but are scarcely ready to endure their deep ingrained antipathy to the desert. ${ }^{11}$ Voss identifies with the destructive bipolar personality within his psyche, which gives him his demonic character. It is unrealistic to idealize him in terms of the Nietzschean Ubermensch because he is the helpless victim of archetypal possession. $^{12}$

Because of his arrogant leadership the exploration into the central desert fails, and finally the party splits into two, one group led by Voss and the other by Judd an ex-convict, and results in death of the group with only one exception. In the end of the novel, White also copies the way in which honors were given by the public to Burke and Wills with the unforgivable neglect of John King. ${ }^{13}$ In this case White has Voss honored and Judd forgotten.

Judd, the only survivor but is insane by the time he reaches a European settlement and finds that his wife and children have died. Judd has sympathy for the loss of his partners and family. He recounts to Laura, at the ceremony of dedication of Voss's statue, 'It was me who closed his eyes' (444) showing how he feels sorry for his death.

Judd has succeeded in dealing with nature's laws, but he is regarded as a villain and coward by the public. White shows his sympathy to Judd for the public is unfair to him, while in his view Voss is somewhat twisted. But is dead and gone. (443)

White portrays his hero as being more paranoid than Hitler who aspired to conquer the whole world, whereas Voss even wants to subdue nature. He has neither fear nor respect for the natural system, that is the reason for his failure, failure in the expedition, failure in his leadership and life.

The hero, completely egocentric, regards himself as a god, ignoring others'existence, he alone decides everything, his thoughts and actions coincide with Hitler's famous words: 'Soldiers need not think, I think everything for you.'

From the failure of the expedition White proves that neither Voss, a god-like character, nor the public understand how important it is to know and obey the law of the nature.

\section{Incapable of Agape, of Eros, of Any Love}

The other lead character of the story, Laura Trevelyan, an intelligent, quiet and inexperienced young woman has, on a brief meeting, become bound by a mysterious, magnetic force to Voss, a compelling attraction unrelated to physical desires of either lust or love. White chooses to invent, in his concentrated poetic style a vivid, brutal, and wrenching story centered round the characters of Voss and his association with Laura Trevlyn, an orphan living with her uncle, the expedition's patron.

Voss and Laura meet when he first visits her uncle to plan the expedition. For his arrogant character Voss even

\footnotetext{
${ }^{11}$ Cranston, C.A.,Zeller, Robert, Literature in the Arid Zone: Australian Contexts and Their Writers Jan.01, 2007, Rodopic, Amsterdam, ISBN:9789401204514 p. 82

${ }^{12}$ David Taccey: Patrick White, Fiction and unconscious, [M] Melbourne Oxford University Press Auckland Oxford New York 1988, p.69,

${ }^{13}$ Manning Clarke's History of Australia, abridged by Michael Cathcart, ISBN 070116124 8, Published Chatto\&Windus limited 1994.
} 
abandons his own male nature: he refuses to admit that he is attracted by feminine beauty. Mr. Bonner, one of his principal patrons asks Voss if he is confident of their compatibility, Voss answers evasively: "I am of every assurance that I can lead an expedition across this continent..." With this answer, Laura's family 'dismisses Voss as a "madman"' (27). Only Laura, blinded by love, argues that Voss is "not afraid' of this country, whereas 'everyone [else] is still afraid, most of us...' (28) He is a god in her eyes, whatever he says or does is right, while Voss's attitude is quite different.

At the first sight of Laura, he ruthlessly admits Laura's beauty, yet he has always considered himself free of the need for a beautiful woman. Laura has a similar delusion, having convinced herself that she is "contemptuous of men". The two delusions are to clash head-on as the story progresses. A symbiotic relationship arises between the two as her weakness feeds his strength and gains its own strength when she realizes he needs her weakness to contrast his being strong. ${ }^{14}$

Unfortunately Laura does not belong to Voss, only the spirit of the land belongs to him and yet he has no sense of man qua child of nature. Of course he can not truly wed the Great Mother Nature for she is too vast, amorphous and collective. ${ }^{15}$ As a child of Nature how can Voss commit incest and wed his mother? Though man is nature's highest development, how can he be more powerful than nature? In reality Voss never shows his respect for nature or nature's system. He desires only to conquer, to prove the strength of his will.

The development of their ensuing relationship parallels the fate of the expedition. Before his departure, Voss and Laura meet in a garden, which seems to them the Garden of Eden. Although they have met totally but a few times, they indulge in overwhelming, obsessive feelings and idealize their hallucination that they have already become soul-mates and belong to one another. This emotion of self indulgence seems to be unsuitable for Voss the leader of an almost improbable adventure. With little prudence they exchange letters affirming their deepening relationship, and come in fact to believe each other to be husband and wife even though most of their letters go astray, never received in an uninhabited country.

Their romantic story ends twenty years later, at a garden party hosted by Laura's cousin Belle Radclyffe, on the day of the unveiling of a statue of Voss. At last Laura speaks out what the writer concludes at end of his novel, "...he is not God, he is nearest to becoming so" (387) Laura's interpretation of Voss as a proud man who was "truly humbled" "16, and 'justly so'.

\section{Conclusions}

The expedition was a failure not only because of the lack of wisdom on the part of Voss, but also from his inverse inferiority complex which assumes vices to form a suitable basis for love and leadership. And so he develops an

\footnotetext{
${ }^{14}$ David Taccey: Patrick White, Fiction and unconscious, Melbourne Oxford University Press Auckland Oxford New York 1988,71

15 Ibid.:78

16 Ibid.:84
}

unsustainable arrogance of self, a catastrophe in a human being. It follows that such a leader of a group causes destruction of the group, a leader of a nation destroys a whole nation or even the whole world, and a lover to destroy whom he loves.

White believes human beings can never conquer nature except perhaps only in their imagination, or by an omnipotent god. Weak human beings must attempt to live in harmony with nature, with an understanding of the laws of nature, that is man qua child of nature, otherwise disasters are waiting for them.

The purpose of the novel gave White the opportunity not only to expose the conflict between the European and the Stone Age culture but also to show that the later in their evolution were adapted to the pristine Australian wilderness, while the former were ignorant of the hostility of the desert harshness. The Aborigines have an understanding of simply living in harmony with nature, which has disappeared from the urbanized European civilization.

Thus in Voss White shows us that human beings can never aspire to be a god, or to control the world. As the German philosopher Heidegger says: 'To rescue the land is neither to control, nor to conquer it.' 17 Human beings including Aborigines are part of the nature, all created equal by god; no one can flourish from the conquest of others.

In White's view, Australian immigrants' response to their new surroundings as human beings must be to adapt to the Australian environment and live in harmony with nature and its Aboriginal peoples; the alternative for them is to become victims of their selfish pride. How to adjust our actions to live in harmony with the nature there are still a lot of secrets waiting to be discovered, however White has revealed something in this novel.

\section{References}

[1] Patrick White, Voss New York 1957.

[2] David Taccey: Patrick White, Fiction and unconscious, Melbourne Oxford University Press Auckland Oxford New York 1988.

[3] Martin Heidegger Voträge und Aufsätze Beijing: Sanlian Bookstore 2005

[4] Cranston, C.A., Zeller, Robert, Literature in the Arid Zone: Australian Contexts and Their Writers Jan.01, 2007, Rodopic, Amsterdam, ISBN:9789401204514

[5] John A. Weigel Patrick White Miami University, Twayne Publishers. 1983.

[6] Lansing, Alfred. Endurance; Shackleton's Incredible Voyage. New York: McGtaw-Hill, 1959

[7] Henry Thoreau, Walden http://www.gutenberg.org/catalog/world/readfile?fk_files=2121329)

[8] Scott Slovic, Seeking awareness in American Nature Writing University of Utah Press 1992. 8

\footnotetext{
${ }^{17}$ Martin Heidegger Voträge und Aufsätze Beijing: Sanlian Bookstore 2005
} 